\title{
Propriedade Urbana no Ordenamento Brasileiro
}

Fernanda Lousada Cardoso'

\section{Introdução}

O direito de propriedade revela uma das mais caras liberdades individuais. Sua configuração, conforme o momento histórico, influenciou a orientação do sistema econômico vigente, consistindo elemento relevante na dinâmica da vida em sociedade. ${ }^{2}$

Estandarte maior do Direito Civil, a regulação do patrimônio foi historicamente formulada com base na ótica individual, buscando preservar a riqueza reunida pelo particular, estabelecendo limites à atuação estatal.

No entanto, o advento do Estado Social e a imputação à Administração Pública de prestações positivas, bem como o incremento das grandes aglomerações urbanas evidenciaram a necessidade de tutelar direitos coletivos, pertencentes a todos igualmente, na busca do bem-estar social.

Nesta conjuntura, a propriedade urbana, antes moldada basicamente sob a ótica liberal civilista, passa a ser nomeada direito fundamental, princípio constitucional, apresentando uma função social a ser exercida pelo proprietário. ${ }^{3}$

\footnotetext{
1 Procuradora do Município do Rio de Janeiro, Mestre em Direito da Cidade pela UERJ.

2 Um robusto histórico da propriedade pela história da civilização é encontrado em VAZ, Isabel. Direito econômico das propriedades. Rio de Janeiro: Forense, 1993.

3 “O tratamento jurídico do instituto da propriedade, portanto, em sua evoluçāo histórica, entre nós, resume-se nisto: na concessão, pelo direito, de maior ênfase ao aspecto da função social da propriedade, inerente a esse direito desde sua origem. Não se trata de um elemento novo, acrescido ao conceito de propriedade ou ao seu direito." MUKAI, Toshio. Direito e legislação urbanística no Brasil: história - teoria - prática. São Paulo: Saraiva, 1988. p. 63.
} 
No âmbito da normativa civil-constitucional, fortalecida com o advento da Carta de 88 e o Código Civil de 2002, verificamos a eleição pelo legislador de alguns princípios basilares a nortear todo o regramento das relações jurídicas dominiais. Entre eles, encontramos a função social da posse e da propriedade urbana realçando o aspecto econômico do bem, delineando seu uso em atenção aos interesses proprietários e não-proprietários, conforme os valores coletivos vigentes.

O reconhecimento de uma função dos institutos pode ser indicado como reflexo de uma ideologia maior, hoje identificada como a corrente da despatrimonialização ${ }^{4}$ do Direito Civil. Esta linha de pensamento trabalha a idéia do sujeito como titular de necessidades, e não apenas de direitos e obrigaçōes patrimoniais.

Ademais, no cenário das grandes cidades, a realidade dos dias de hoje demanda uma forte atuação do Direito Urbanístico sobre a propriedade, definindo-lhe um regime peculiar. Mister se faz uma ordenação da ocupação do espaço urbano, confeccionada a partir de interesses coletivos, pautada na qualidade de vida dos cidadãos, não sendo sujeita à discricionariedade do proprietário privado.

O breve estudo pretende abordar, ainda que de forma sucinta, os diversos prismas por meio dos quais a propriedade urbana é regulamentada em nosso ordenamento jurídico, destacando os vários interesses envolvidos, públicos, coletivos e privados, patrimoniais e extra-patrimoniais.

A finalidade última desta coletânea é uniformizar conceitos, viabilizando a extração do máximo de efetividade da norma, de modo a realmente interferir na dinâmica urbana, potencializando a função social da cidade.

\section{Evolução histórica}

Como já se disse, a forma de regulamentação da propriedade muito revela sobre o regime político-econômico estabelecido. Em Roma, há notícias de a propriedade ser exercida com muitos dos atributos hoje inerentes ao domínio, como a exclusividade. ${ }^{5}$ A religião influenciou no estabelecimento do direito real matriz, contribuindo para a tríade família-religião-propriedade, apresentada como a constituição social ${ }^{6}$ dessa organização, estabelecendo a ordem dos bens nas

\footnotetext{
4 A percepção de novos valores a serem identificados nos institutos privados patrimoniais é uma das diretrizes do Direito Civil Constitucional, expondo sobre tais institutos Perlingieri: "São sempre, porém, inclinados a adequar-se aos novos 'valores', na passagem de uma jurisprudência civil dos interesses patrimoniais a uma mais atenta aos valores existenciais. Estes nāo podem mais ser confinados aprioristicamente no papel de limites ou de finalidades exteriores, como se não fossem idônecs a incidir sobre a funçāo do instituto e portanto sobre a sua natureza." PERLINGIERI, Pietro. Introdução ao direito civil constitucional. Trad. de Maria Cristina De Cicco. Rio de Janeiro: Renovar, 1999. p. 33.

5 Estas notícias nos são passadas en COULANGES, Fustel de. A cidade antiga. Trad. Jean Melville. São Paulo: Martin Claret, 2004. p. 65.

6 Expressāo cunhada por Fábio Konder Comparato, encontrada em COMPARATO, Fábio Konder. Direitos e deveres fundamentais em matéria de propriedade. Revista do Ministério Público do Rio de Janeiro. Rio de Janeiro, v. 4, n.7, p. 73-87, jan./jun. 1998, p. 74.
} 
cidades romanas. Neste sentido, acreditava-se que cada família era protegida por um deus, que por ela olhava, devendo a divindade possuir uma morada fixa. $\mathrm{O}$ aspecto religioso também influenciará a separação física entre as casas, hoje por nós conhecido como afastamento.

A Lei das XII Tábuas dedicou a Tábua Sexta ${ }^{7}$ para regular a propriedade e a posse, prevendo àquela época o instituto da usucapião, que possibilitava a aquisição da propriedade pelo exercício da posse.

Com o surgimento das cidades, a propriedade imobiliária passa a sofrer limitaçōes devido ao necessário ordenamento do espaço urbano, sendo atravessada por aquedutos e restringida em razão da abertura de ruas e áreas públicas. ${ }^{8} \mathrm{~A}$ própria Lei das XII Tábuas, no período pós-clássico, ampliou as distâncias entre as construções nas cidades e previu a impossibilidade de levantar edificação que atingisse o vento do terreno vizinho. ${ }^{9}$

$\mathrm{Na}$ Idade Média, o arrendamento apresentou-se como o grande instrumento propiciador da exploração da terra, ocasionando uma cisão no direito real, vez não ser, em regra, o proprietário aquele que tornava a área produtiva, mas sim seu vassalo, titular do domínio direto. O arrendatário devia ainda ao seu senhor o pagamento de determinada quantia, prestando-lhe também dever de fidelidade militar.

Já na época das revoluções burguesas, a Declaração Universal dos Direitos do Homem e do Cidadão equiparou a propriedade à liberdade, qualificando-as, em seu art. $2^{\circ},{ }^{10}$ como direitos naturais e imprescritíveis. $O$ art. 17 expressa a garantia ao direito de propriedade, admitindo sua privação apenas em casos de necessidade pública, mediante justa e anterior indenização. ${ }^{11}$

Em momento seguinte, a doutrina social da Igreja, rebatendo o regime socialista já firmado na União Soviética, afirma a necessidade da propriedade privada se dar não apenas em benefício do particular, mas também do bem comum, servindo sempre à utilidade pública, de modo a viabilizar a justa distribuiçāo de riquezas entre os homens. ${ }^{12}$ Este entendimento será seguido em Mater et Magistra, ao se

MOURA, Paulo César Cursino de. A Lei das XII Tábuas: fonte de direito público e privado. Rio de Janeiro: Forense, 1998.

* HAROUEL, Jean-Louis. História do urbanismo. Trad. Ivone Salgado. Campinas: Papirus, 1990.

- MOREIRA ALVES, José Carlos. Direito romano. 7. ed. rev. e acrescentada. Rio de Janeiro: Forense, 1998. v. 1, p. 286-289.

10 "Sobre este aspecto de garantia da liberdade individual, a propriedade passou a ser protegida constitucionalmente em sua dupla natureza, de direito subjetivo e de instituto jurídico. Nāo se trata, apenas, de reconhecer o direito subjetivo dos proprietários, garantindo-os contra as investidas dos demais sujeitos privados ou do próprio Estado. Cuida-se, também de evitar que o legislador venha a suprimir o instituto, ou a desfigurá-lo completamente, em seu conteúdo essencial." COMPARATO. Op. cit., p. 77.

Declaração dos Direitos do Homem e do Cidadão. In: Direitos humanos: instrumentos internacionais, documentos diversos. Brasília: Senado Federal, Subsecretaria de Ediçōes Técnicas, 1990.

12 "O perfil mais significativo é constituído pela obrigação, ou dever, do sujeito titular do direito de exercê-lo de modo a nāo provocar danos excepcionais a outros sujeitos, em harmonia com o princípio 
utilizar a expressão função social da propriedade para afirmar que os bens deverão satisfazer às necessidades que não possam ser atendidas pela assistência pública.

O conteúdo da propriedade imobiliária recebe tratamento constitucional nas Cartas de Weimar e do México, admitindo-se a possibilidade de exploração de riquezas em prol do interesse coletivo.

Tais documentos serviram de inspiração para as Cartas Constitucionais brasileiras. A Constituição de 1934 previu em seu art. 113, alínea 17, a garantia à propriedade, nāo podendo seu exercício contrariar o interesse social ou coletivo, na forma da lei. Tal dispositivo já revela o conteúdo do princípio da função social da propriedade na normativa nacional.

Em 1946, com o fim do regime de Getúlio Vargas, é elaborada nova Constituição, garantindo a propriedade, mas condicionando seu uso ao bem-estar social, conforme o texto expresso do art. 147. Trata-se da primeira previsão constitucional determinando condicionamento ao exercício da propriedade.

Na Constituiçāo de 1967, surge, pela primeira vez, em sede constitucional, a expressāo função social da propriedade, nomeada entre os princípios da ordem econômica, prevendo-se, ainda, a desapropriação mediante pagamento de títulos da dívida pública, na linha do art. 157.

A atual Carta Constitucional tratou expressamente da função social da propriedade, prevendo-a como direito fundamental (art. 5ㅜ, XXIII). Há, portanto, avanço revelado na nova tipologia da função social da propriedade, não mais como princípio da ordem econômica, ou pelo menos não apenas como tal, ganhando vestimenta de cláusula pétrea, por consistir direito fundamental. ${ }^{13}$

No entanto, a doutrina ${ }^{14}$ lamenta a redação independente, não vinculando diretamente o conteúdo de tal direito ao seu exercício social, como expressamente previsto nas Constituiçōes alemãs de 1919 e 1949 e na Constituição espanhola de 1978.

A contribuição dos textos constitucionais mais atuais não foi a de identificar a existência da função social, mas dotá-la de eficácia e coercibilidade. Em alguns casos, revelou-se expressamente a existência de obrigações decorrentes do direito real, não conferindo apenas direitos a seu titular. ${ }^{15}$

de solidariedade política econômica e social. Isso incide de tal modo sobre o direito subjetivo que, em vez de resultar como expressāo de um poder arbitrário, acaba por funcionalizá-lo e por socializá-lo." PERLINGIERI. Op. cit., p. 120-121.

13 CALLAGE, Carlos. Função social da propriedade (CF, art. $\left.5^{\circ}, X X I I I\right)$. Dever imposto ao proprietário. Disponivel em: < http://www.pge.sp.gov.br/Congresso/ztese16.html >. Acesso em: 17 nov. 2005. p. 10.

${ }_{14}$ "O legislador constituinte sempre opta por inovações meramente cosméticas, por saber que a propriedade é fato que se orna de dimensão estrutural. Responde pelas relaçōes sociais de base e ele sabe que democratizar o seu domínio e atribuir-lhe uma obrigatória função social é 'mexer em casa de marimbondo'." BRITTO, Carlos Ayres. Direito de propriedade: o novo e sempre velho perfil constitucional de propriedade. Revista de Direito Público, São Paulo, v. 22, n. 91, p. 44-51, jul./set. 1989, p. 46.

15 Constituição da República Federal da Alemanha, de 1949 (art. 14, 2플 alínea): "A propriedade obriga. Seu uso deve, a mesmo tempo, servir de interesse da coletividade" (Eigentum verpflichtet. Sein 
A Carta Constitucional de 1988 inovou também ao prever um capítulo específico dedicado à política urbana, ganhando assento constitucional normas urbanísticas que regulamentam especialmente a propriedade situada nas cidades, trazendo também, neste particular, a observância da função social.

Esta nova perspectiva passou a preponderar no estudo da propriedade imobiliária, em especial a urbana, sendo a função social a pedra de toque do atual ordenamento jurídico brasileiro sobre o tema.

\section{A propriedade urbana na ordem constitucional}

$\mathrm{O}$ texto constitucional vigente estabelece no art. $5^{\circ}$, XXII, o direito de propriedade como garantia fundamental, definindo logo em seguida, no inciso XXIII do mesmo artigo, o atendimento de sua função social. A propriedade privada e sua função social também estarão previstas no art. 170, II e III, CRFB, enunciados como princípios da ordem econômica. ${ }^{16}$

A previsão de que deverá a propriedade atender a sua função social está a delinear o conteúdo do direito fundamental garantido pelo texto constitucional. Seu exercício deve otimizar os recursos disponíveis, dirigindo o bem à sua utilidade social. ${ }^{17}$

A destinação social importa, portanto, a implementação pelo particular da produtividade do bem conforme sua potencialidade, produzindo riqueza de modo a atender a suas necessidades e às do grupo social.

Atualmente, situa-se a função social no núcleo do direito dominial, de modo a relacionar a plena garantia constitucional à sua observância no exercício do direito pelo particular. Trata-se de um elemento fundamental, integrante da própria estrutura do instituto, abrangendo os interesses que se pretende tutelar. ${ }^{18}$

Em outras palavras, reconhece-se que a propriedade que nāo cumpre a função social permanece como direito fundamental, sendo tal status previsto pela norma constitucional. O direito não se desnaturará sem a observância de um de seus elementos; apenas não gozará de proteção na mesma intensidade daquela senhoria que venha a cumprir sua função social.

Gebrauch soll augleich dem Wohle der Allgemeinheit dienen). A Constituiçāo italiana em seu art. 42 prevê: "A propriedade é pública ou privada. Os bens econômicos pertencem ao Estado, a entes ou a particulares. A propriedade privada é reconhecida e garantida pela lei, a qual prescreve os respectivos modos de aquisiçāo e de gozo e os limites a que está sujeita, a fim de realizar a sua funçāo social e de se tornar acessível a tcdos."

16 O estudo da propriedade privada sob este prisma é encontrado em GRAU, Eros Roberto. A ordem econômica na Constituição de 1988: interpretação e crítica. 9. ed. rev. e atual. São Paulo: Malheiros, 2002.

BANDEIRA DE MELLO, Celso Antônio. Novos aspectos da função social da propriedade no direito público. Revista de Direito Público, São Paulo: Revista dos Tribunais, ano XX, n. 84, p. 39-45, out./dez. 1987. p. 43.

18 SCHREIBER, Anderson. Funçāo social da propriedade na prática jurisprudencial brasilcira. Revista Trimestral de Direito Civil. Rio de Janeiro: Padma, ano 2, v. 6, p. 159-182, abr./jun. 2001. p. 161-162. 
Nestes termos, a função social passa a ser importante critério de gradação da proteção jurídica que gozará o direito real durante sua existência e exercício. À propriedade que observa a funçāo social será destinada a mais ampla garantia possível, proteção que não será dispensada ao domínio exercido egoisticamente.

Esta gradação definida pelo constituinte é bem assinalada na fixação do instituto da desapropriação com pagamento de títulos da dívida pública. Destaquese que o pagamento que não em espécie e procedido posteriormente à perda do direito real traduz garantia bem mais singela que a justa e prévia indenização paga em moeda corrente à propriedade que exerça sua função social, prevista no art. $5^{\circ}$, XXIV, CRFB.

A configuração da função social na estrutura da propriedade sugere a este direito um condicionamento, uma finalidade a ser alcançada, limitação não muito comum na seara do Direito Privado, mais usualmente encontrada no Direito Público. ${ }^{19}$

A Carta Constitucional não estabeleceu parâmetros objetivos na aferição do cumprimento da função social, por tal conceito encerrar uma idéia evolutiva, variável conforme o objeto em análise, bem como em razão da estrutura do próprio grupo social, do tempo, do espaço e das regras específicas vigentes, aplicáveis ao caso concreto..$^{20} \mathrm{O}$ conteúdo deste conceito, aprioristicamente indeterminado, será buscado nos princípios que informam a interpretação das normas e em outras fontes de direito, tais como a analogia e os costumes. ${ }^{21}$

O alcance de tal conclusão implica constatar a evolução ${ }^{22}$ que sofreu o instituto. De início, a função social era apresentada como mera indicação programática, despida de efeito imediato na estrutura do direito de propriedade. Num segundo momento, passou a ser identificada como limite externo ao domínio, um condicionamento sem atingir sua estrutura de direito subjetivo.

Hoje, a doutrina ${ }^{23}$ indica a função social como elemento intrínseco à propriedade, revelando os valores e interesses a serem tutelados por este instituto, sem, no entanto, desnaturá-la, persistindo um direito subjetivo individual.

19 SUNDFELD, Carlos Ari. Funçāo social da propriedade. In: DALLARI, Adilson de Abreu; FIGUEIREDO, Lucia Valle (Org.). Temas de direito urbanístico I. São Paulo: Revista dos Tribunais, p. 1-22, 1987. p. 5.

20 "A função social da propriedade não é senão o concreto modo de funcionar da propriedade, seja como exercício do direito de propriedade ou não, exigido pelo ordenamento jurídico, direta ou indiretamente, por meio de imposição de obrigaçōes, encargos, limitaçōes, restriçōes, estímulos ou ameaças, para satisfação de uma necessidade social, temporal e espacialmente considerada." MORAES. Op. cit., p. 111.

21 RABELLO DE CASTRO. Algumas formas diferentes de se pensar e reconstruir o direito de propriedade e os direitos de posse nos países novos. In: FERNANDES, Edésio (Org.). Direito urbanístico e política urbana no Brasil. Belo Horizonte: Del Rey, 77-100, 2000. p. 90.

22 Esta breve evolução é corretamente indicada em PEREZ-LUÑO, Antonio Enrique. Derechos humanos, estado de derecho y Constitución. 6. ed. Madrid: Tecnos, 1999, p. 436-437.

23 "Isto significa que a propriedade, embora concebida e tutelada na forma de sua função social, continua sendo direito subjetivo de seu titular e em seu proveito estabelecida." GONDINHO, André Osório. Função social da propriedade. In: TEPEDINO, Gustavo (Coord.). Problemas de direito civil-constitucional. Rio de Janeiro: Renovar, p. 397-433, 2000. p. 418. 
Esta parece ser a ratio da propriedade tal como ela deve ser estudada e exercida, cumprindo-se assim uma interpretação sistemática do texto constitucional vigente. Neste particular, impõe-se a transcrição da definição de função social da propriedade por Fábio Konder Comparato: ${ }^{24}$

Quando se fala em função social da propriedade não se indicam as restrições ao uso e gozo dos bens próprios. Estas últimas são limites negativos aos direito do proprietário. Mas a noção de função, no sentido em que é empregado o termo nesta matéria, significa um poder, mais especificamente, o poder de dar ao objeto da propriedade destino determinado, de vinculá-lo a certo objetivo. $O$ adjetivo social mostra que esse objetivo corresponde ao interesse coletivo e não ao interesse próprio do dominus; o que não significa que não possa haver harmonização entre um e outro. Mas, de qualquer modo, se está diante de um interesse coletivo, essa função social da propriedade corresponde a um poder-dever do proprietário, sancionável pela ordem jurídica.

O cumprimento da função social encerra, portanto, uma obrigação de fazer ${ }^{25}$ ou não fazer, a ser empreendida pelo proprietário, em atendimento às necessidades sociais, exigíveis pela coletividade em caso de inadimplemento do titular do bem. Integra o direito subjetivo de propriedade por vincular o facultas agendi ao atendimento também do interesse social. Daí por que operar, para alguns, ${ }^{26}$ verdadeira metamorfose qualitativa na propriedade, em especial na situada nas cidades, superando a contraposição entre público e privado.

Neste sentido, a função social da propriedade contribui para a identificação de deveres a serem observados pelo titular do direito real, inseridos na relação jurídica firmada com toda a coletividade, diante da ampla oponibilidade de seu direito, decorrente da eficácia erga omnes.

De fato, antes do reconhecimento de sua função social, só eram atribuídos deveres à coletividade, ocupante da posição passiva universal, não sendo, por definição, apresentados deveres positivos ou prestaçōes àquele que detém a propriedade urbana.

Hoje, a norma definidora da função social identificará direito de terceiros frente ao titular do domínio. A propriedade urbana será reconhecida como fon-

24 COMPARATO. Função social da propriedade dos bens de produção. Revista de Direito Mercantil Industrial, Econômico e Financeiro, São Paulo: Revista dos Tribunais, n. 63, p. 71-79, 1986.

25 "A função social da propriedade leva, especificamente, a que o titular do direito seja obrigado a fazer, a valer-se de seus poderes e faculdades, no sentido do bem-comum." FERREIRA, Sérgio de Andréa. O direito de propriedade e as limitaçōes e ingerências administrativas. São Paulo: Revista dos Tribunais, 1980. p. 8.

${ }^{26}$ GRAU, Eros Roberto. Elementos de direito econômico. São Paulo: Revista dos Tribunais, 1981. p. 119120. No mesmo sentido: VAZ. Op. cit., p. 320. 
te de direitos e deveres fundamentais, ${ }^{27}$ reveladores do lado passivo dos direitos humanos alheios. ${ }^{28} \mathrm{O}$ solo urbano encerra interesses privados a serem satisfeitos, consistentes nos direitos do dono do bem, sendo o domínio oponível à coletividade. Correspondente a este direito, há um dever geral de abstenção na ingerência do objeto, na medida, e aí está o detalhe, na medida em que esta ingerência venha também a satisfazer os interesses coletivos. Respeitando-se os direitos da comunidade local, observa-se a função social do imóvel. Há, portanto, dois direitos interdependentes incidentes sobre o mesmo bem. ${ }^{29}$

Uma situação de direitos e deveres fundamentais ${ }^{30}$ é identificada, sendo suas normas definidoras dotadas de aplicação imediata. Os deveres fundamentais, distintamente do que ocorre com os direitos, não são apenas reconhecidos pelo constituinte, mas por ele criados, remetendo ao legislador ordinário o dever de concretização da norma.

No caso específico da propriedade urbana, tal assertiva é facilmente verificável na leitura combinada do art. 5o, XXIII, com o art. 182, ambos do texto constitucional. Podemos afirmar que o dispositivo inserido no capítulo da política urbana já traz contornos concretos da função social da propriedade urbana, elencando instrumentos que suscitem no proprietário a observância de seu dever.

No entanto, não se deve confundir a função social do direito de propriedade com o poder de polícia incidente sobre o solo urbano. As limitações administrativas são sempre previstas por lei e determinam uma ingerência na propriedade urbana fundada no interesse público. O texto legal que a institui descreve o conteúdo jurídico, definindo a competência, a forma e a extensão de modo a bem delinear a restriçāo imposta. ${ }^{31}$

Para o fim de alcançar o correto cumprimento da restrição legal imposta pela limitaçāo administrativa, o Poder Executivo exerce seu poder de polícia, fiscali-

\footnotetext{
2:- "Os deveres fundamentais constituem uma categoria jurídica constitucional própria. Uma categoria que, apesar disso, integra o domínio ou a matéria dos direitos fundamentais, na medida em que este domínio ou esta matéria polariza todo o estatuto (activo e passivo, os direitos e os deveres) do indivíduo." CASALTA NABAIS, José. A face oculta dos direitos fundamentais: os deveres e os custos dos direitos. Revista da Advocacia-Geral da União. Disponível em: <http://www.agu.gov.br/agu.htm> Acesso em: 25 out. 2005

28 "Importa não esquecer que todo direito subjetivo se insere numa relaçāo entre sujeito ativo e sujeito passivo. Quem fala, pois, em direitos fundamentais está, implicitamente, reconhecendo a existência correspectiva de deveres fundamentais." COMPARATO. Direitos e deveres... Op. cit., p. 82.

29 RABELLO DE CASTRO. Algumas formas... Op. cit., p. 85.

30 "A sua inserção no rol das garantias constitucionais cria a conviç̧ão de que o direito de propriedade possui, além dos poderes que lhe são inerentes, deveres comuns aos direitos patrimoniais, em proveito da sociedade. A propriedade contém poderes e deveres. O direito individual sobre as coisas impõe obrigaçōes. O uso da propriedade há de contribuir para o bem da coletividade." AGULAR, Joaquim Castro. Direito da cidade. Rio de Janeiro: Renovar, 1996, p. 8.

31 "Limitaçōes dizem respeito ao exercício do direito, ao proprietário; enquanto a funçāo social interfere com a estrutura do direito mesmo." SILVA, José Afonso da. Direito urbanístico brasileiro. Sāo Paulo: Malheiros, 2000. p. 71.
} 
zando e controlando o respeito ao interesse público ali presente. ${ }^{32}$ Vincula, assim, a atividade do proprietário, sendo externo ao direito, consistindo em requisito para o seu exercício.

Em sentido distinto, fala-se na função social da propriedade. Esta integra a estrutura do direito que se pretende exercer, inserindo-se no fundamento do seu regime jurídico. Não há condicionamento ou limitação, sendo a própria essência do direito a revelar seu dever correlato às faculdades atribuídas pelo texto legal.

Sobre o tema de difícil abordagem, ${ }^{33}$ esclarecedoras as palavras de Carlos Ari Sundfeld que bem sintetiza a questão sob o seguinte prisma: "No primeiro caso, o das limitaçōes, trata-se de condição para o exercício de direito. No segundo (função social), trata-se do dever de exercitar o mesmo direito." 34

Ademais, a propriedade sendo elemento do direito econômico, na esteira do disposto no art. 170, CRFB, não mais será considerada apenas direito individual, sendo objeto de estudo do Direito Público sob diversos prismas, entre eles o econômico. Seguindo a doutrina do professor José Afonso da Silva, só será plenamente garantida como tal, caso venha a "assegurar a todos existência digna, conforme os ditames da justiça social", ${ }^{5}$ na forma expressa do art. 170, caput.

A função social é um princípio informador da ordem econômica, devendo ser reconhecido como plenamente eficaz, dotado de aplicabilidade direta e imediata. Não se vincula à edição posterior de norma reguladora, vigendo desde o advento do texto constitucional. ${ }^{36}$

Por outro lado, destaque-se não ser o conteúdo da função social necessariamente definido por normas de Direito Público. Outrossim, sua observância poderá ensejar o surgimento não só de direitos subjetivos públicos, mas também de direitos oriundos de normas de interesse social ou de regras de ordem pública de Direito Privado, conforme o interesse que se pretenda ver tutelado.

O princípio da função social revela, desta forma, ideais coletivos de forma que "a moderna concepção de propriedade é aplicada à preservação de uma situação de equilíbrio entre o individual e o social". ${ }^{37}$

\footnotetext{
32 Adotamos aqui o conceito trazido por RABELLO DE CASTRO. O poder de polícia normativo, o direito urbanistico, $e$ as normas de planejamento urbano. Rio de Janeiro: UERJ. Tese elaborada como requisito parcial para o concurso ao cargo de professor titular de Direito Administrativo da Faculdade de Direito da UERJ. Mimeo. 2001, p. 54-57.

33 "Note-se que, quando se fala em obrigação positiva, o poder de polícia se distingue mal da idéia de função social da propriedade." Esta é a constataçāo extraída de DI PIETRO, Maria Sylvia. Poder de polícia em matéria urbanística. Temas de direito urbanistico. São Paulo: Ministério Público/Imprensa Oficial, p. 23-38, 1999. p. 24.

34 SUNDFELD. Funçāo social... Op. cit., p. 11.

35 SILVA, José Afonso da. Comentário contextual à constituição. São Paulo: Malheiros, 2005 p. 712.

36 SILVA, José Afonso da. Aplicabilidade das normas constitucionais. 6. ed. 3. tir. Sāo Paulo: Malheiros, 2004, p. 144.

3: GRAU, Eros Roberto. Aspectos jurídicos da noção de solo criado. Revista dos Tribunais, São Paulo: Revista dos Tribunais, v. 504, p. 11-25, out. 1977. p. 15.
} 
Isto porque, paralelo ao direito fundamental da propriedade, teremos o direito fundamental da moradia, do trabalho, do lazer, do meio ambiente. Apenas será reconhecido o primeiro se exercido em harmonia com os demais, atendendo-se, assim, as necessidades tuteladas pelo sistema constitucional.

No capítulo constitucional dedicado à ordem urbana, em especial nos arts. 182 e 183, juntamente com o art. 21, XX, há a definiçāo da competência da União para instituir diretrizes para o desenvolvimento urbano, alicerces da política nacional de desenvolvimento urbano.

Nos termos do art. 182 da Constituição da República, cabe ao Poder Público Municipal implementar o desenvolvimento urbano, propiciando o bem-estar de seus habitantes, viabilizando a efetivação da função social das cidades.

O que se verifica, portanto, é o estabelecimento de um regime próprio da propriedade urbanística, a ser constantemente modelado por valores sociais. Não se delegam ao proprietário particular as definiçōes primordiais sobre urbanismo, sendo estas estabelecidas pelo Poder Público local. ${ }^{38}$

Com base numa nova perspectiva da propriedade urbana, considerada eixo central de relações jurídicas diversas, extraímos uma releitura do domínio situado em solo urbano, desenvolvido de modo a atender às funçōes básicas da cidade de moradia, trabalho e lazer, além da circulação dos seus habitantes, satisfazendo também os interesses privados de seu dono.

Enfatizando os interesses sociais revelados na firmação de uma política de uso adequado do solo urbano, o ordenamento jurídico passa a viabilizar a limitação do atributo da perpetuidade do domínio. Autoriza, em algumas situaçōes, o destacamento do direito de construir do direito de propriedade, estabelecendo um novo conteúdo à propriedade urbanística.

Neste passo, mereceu destaque especial do constituinte de 1988 a função social do domínio urbano, definindo que seu regramento será determinado pelo plano diretor municipal, nos termos do art. $182, \$ 2^{\circ}$, CRFB. A propriedade urbana submete-se, assim, à função pública da atividade urbanística. ${ }^{39}$

Destarte, a diretriz constitucional é no sentido de estimular o proprietário a destinar seu bem de raiz à finalidade condizente com o desenvolvimento social da cidade, coibindo a inércia sustentada pela especulação imobiliária, alimentada pelo gradual crescimento do espaço urbano.

\footnotetext{
38 A configuração da cidade é ônus do poder público municipal, sob pena de se consagrar a mais absoluta anarquia urbanística, tomando aqui emprestada a expressão cunhada pelo Mestre Ricardo Lira. Elementos de direito urbanístico. Rio de Janeiro: Renovar, 1997, p. 159-160.

39 "Nesse contexto, o poder do proprietário de deliberar sobre o aproveitamento de seu terreno urbano vai cedendo lugar ao interesse coletivo, de modo que a faculdade de construir, em local de especial interesse urbanístico, passaria a revestir-se do conteúdo de uma função pública, daí porque estaria inteiramente superado o sistema no qual os proprietários eram os protagonistas do processo urbanístico." CHALUB, Melhim Namem. Propriedade imobiliária: função social e outros aspectos. Rio de Janeiro: Renovar, 2000. p. 20.
} 
Nesta linha, o art. 182, $\$ 4^{\circ}$, estabelece o rol de obrigações a serem impostas pelo Poder Público Municipal ao proprietário urbano que não estiver dando adequada destinação a seu imóvel. Em ordem sucessiva, exigir-se-á do particular o parcelamento ou edificação compulsória; cobrar-se-á IPTU progressivo no tempo e, por fim, impor-se-á desapropriação com pagamento em títulos da dívida pública. Tais instrumentos foram regulamentados pela Lei 10.257/01.

Não obstante seja um avanço na previsão da política urbana, o dispositivo constitucional em comento apresenta notas das forças políticas conservadoras. Destarte, há a previsão de ordem sucessiva da aplicação dos dispositivos que, por serem autônomos e independentes, poderiam ter sua aplicação efetiva conforme $o$ caso concreto, a critério do poder discricionário da Administração Pública. ${ }^{40}$

Ressalte-se, ainda, que a espécie de desapropriação aqui prevista não deverá observar a garantia fundamental da justa e prévia indenização, plasmada no art. $5^{\circ}$, XXIV, da Carta Maior, justamente por existir uma disfunção no uso da propriedade urbana, deixando de ser esta plenamente garantida pelo ordenamento constitucional. ${ }^{41}$

\section{A propriedade urbana no Código Civil}

Estabelecidas as diretrizes constitucionais sobre as quais se funda a propriedade urbana, passamos agora a nos ocupar do tratamento dispensado pela legislação civil ao instituto jurídico objeto de nosso estudo.

O texto constitucional aqui comentado trabalha com o conceito de propriedade como qualquer direito patrimonial. Já a legislação civil trará a propriedade num conceito mais estrito, sendo sinônimo de domínio, ${ }^{42}$ consistindo no poder jurídico sobre a coisa ou direito, exercido diretamente e oponível a terceiros.

$\mathrm{Na}$ organização do Código Civil, a propriedade está inserida dentre os direitos reais. A qualificação do direito como real vem do vocábulo res em latim, significando direito da coisa. Na lição de Clovis Bevilacqua, ${ }^{43}$ coisa se distingue de bem, sendo este mais amplo, abrangendo tudo aquilo que concorre para satisfazer a necessidade humana.

Segundo a normativa civilista, a definição do direito real matriz pode ser implementada sob prisma analítico, trazendo os atributos que são reconhecidos ao

\footnotetext{
to No mesmo sentido consulte-se LIRA. Op. cit., p. 366.

${ }^{+1}$ Consulte-se COMPARATO, Fábio Konder. Estado, empresa e funçāo social. Revista dos Tribunais, São Paulo: Revista dos Tribunais, v. 85, n. 732, p. 38-46, out. 96, p. 43.

42 Explica Fábio Konder Comparato que, na língua latina, tanto dominus e dominium vêm de domus, significando, respectivamente, chefe da casa e poder próprio sobre os bens familiares. Consulte-se COMPARATO. Direitos e deveres... Op. cit., p. 74.

43 BEVILACQUA, Clovis. Theoria geral do direito civil. 5. ed. Actual. Achilles Bevilaqua. Rio de Janeiro: Francisco Alves, 1951.p. 13.
} 
seu titular de usar, gozar e dispor da coisa e ainda de reavê-la de quem injustamente a possua, nos termos do art. 1.228, CC.

Abordamos, assim, o aspecto interno da propriedade urbana, relativo às faculdades intrínsecas à senhoria, reveladoras de seu viés econômico. Existe, ainda, o aspecto externo ou jurídico do domínio, consistente na exclusão pelo dono de ingerências alheias ao bem. ${ }^{44}$ Insere-se nesta perspectiva o direito de reivindicação da terra urbana.

Os atributos dominiais devem ser realizados sob o prisma da função social do bem. Assim, o poder de escolha do dono à finalidade do solo urbano, ao uso que lhe será dado, vem sendo gradualmente limitado pelo necessário atendimento aos interesses sociais. Tal restrição ainda se refletirá no exercício da fruição, ou seja, na produção e destinação dos frutos oriundos da utilização dada ao imóvel pelo seu titular. Também a disposição ${ }^{45}$ pelo proprietário da terra urbana vem fortemente regulada pela legislação urbanística incidente sobre o imóvel.

Desta forma, verifica-se no ordenamento jurídico a tendência de restringir gradativamente o caráter totalitário deste direito real, ${ }^{46}$ apresentando-se tal limitação mais intensa no exercício do domínio em solo urbano.

No mesmo sentido a perpetuidade, caracterizada pela duração ilimitada do direito real matriz, não mais subsiste na propriedade urbana, em razāo da previsão do instituto do parcelamento e edificação compulsórios.

Já a exclusividade, prevista no art. 1.231, CC, somente será plenamente exercida por seu titular, que assim poderá reivindicar o terreno, caso esteja dando bom uso ao solo urbano. De outro modo, estando o possuidor a promover a sua função social, dificilmente alcançará o proprietário sucesso na sua reivindicação.

As limitações ao exercício da propriedade urbana sempre tiveram previsão na legislação nacional, seja para proteger o interesse de terceiros particulares, como no caso dos direitos de vizinhança, seja na preservação do interesse público, ${ }^{47}$

\footnotetext{
44 "Os direitos reais têm por objeto imediato uma coisa, com a qual estabelece seu titular um liame estreito, direto, sem intermediário. A situaçāo jurídica assim constituída tem caráter absoluto, criando um dever jurídico negativo, prevalecente contra todos - erga omnes -, que deverão respeitar o exercício do direito, abstendo-se de qualquer ingerência." TEPEDINO, Gustavo. Multipropriedade imobiliária. Sāo Paulo: Saraiva, 1993. p. 58.

45 "Por outro lado, o Projeto brasileiro, na intençāo de desfazer errôneas suposiçōes de excessivo individualismo atribuído ao jus abutendi dos romanos, a que, naturalmente, corresponde o nosso dispor, preferiu dizer utilizar-se de seus bens. O pensamento, assim expresso, levava o intuito de acentuar que o direito de propriedade não tinha o caráter absoluto, que alguns lhe atribuíam." BEVILACQUA, Clovis, Direito das coisas. Atual. José de Aguiar Dias. 4. ed. Rio de Janeiro: Forense, 1956. v. 1, p. 113.

46 "O direito de propriedade assegurado no Código Civil nada tem de absoluto, como o entendiam os antigos, podendo ser sacrificado ou modificado onde quer que surja a necessidade de atender aos reclamos do interesse geral ou da coletividade. É absoluto, sem dúvida, mas tão-somente enquanto não tiver a coletividade necessidade de restringi-lo." CARVALHO SANTOS, João Manuel de. Código Civil brasileiro interpretado. 11. ed. Rio de Janeiro: Freitas Bastos, 1987. v. VII, p. 273.

4: "As regras de ocupação do espaço urbano são regras de direito público porque se supōe que elas exijam dos indivíduos que ocupam os espacos urbanos determinados padrōes, em função de interes-
} 
tutelado em diversas normas administrativas relativas ao meio ambiente natural e urbano. Tais disposições agora também estão previstas na lei civil, art. $1.228, \mathbb{\$} 1^{\circ}$, que encerra um conjunto de interesses sociais não dominiais.

Desconsiderar tais fronteiras legais caracteriza abuso de direito, na medida em que seu exercício vai além do conteúdo jurídico que lhe foi conferido, ultrapassando os parâmetros impostos pela ordem jurídica, como definido no art. 187, CC. ${ }^{48}$

O que se verifica na regulação da dominialidade é a previsão específica contrária ao abuso de direito, determinando a vedação aos atos emulativos nos arts. $1.228, \$ 2^{\circ}$, e $1.229, \mathrm{CC}$, bem como a negativa de validade de toda e qualquer convenção que venha a contrariar preceitos de ordem pública garantidores da função social da propriedade, ${ }^{49}$ na forma do art. 2.035, parágrafo único, CC.

Por outro lado, a identificação do abuso de direito poderá variar em razão do tempo, de sua intensidade, dos usos e costumes locais, até porque representará uma contrariedade ao seu fundamento social, ${ }^{50}$ este, por essência, um valor histórico.

Hoje, é consentâneo que a propriedade urbana deva ser exercida regularmente, observando os limites que a restringem. Sua essência é revelada por meio da posse, instrumento primordial na realização de valores econômicos e sociais. ${ }^{51}$

Ao proprietário urbano cumpre observar a função social de seu direito, satisfazendo sua necessidade pelo uso do bem. Impōe-se registrar que o cumprimento

ses gerais, sejam eles sanitários, de segurança, estéticos, ambientais, culturais, ou para implantaçāo de serviços públicos." RABELLO DE CASTRO. Regularizaçāo fundiária e o sistema jurídico. Uma introdução ao tema. Curso Regularização Fundiária e Urbanística de Assentamentos Irregulares. IBAM, S. 1., 2005, p. 19-26., p. 23.

48 PONTES DE MIRANDA, Francisco Cavalcanti. Tratado de direito predial. Rio de Janeiro: José Konfino, 1947. v. 1, p. 95.

49 "Como elemento interno do domínio, a funçāo social é responsável pelo controle de legitimidade funcional do direito de propriedade, impondo ao titular o dever de respeitar situaçōes jurídicas e interesses não-proprietários socialmente tutelados, atingidos pelo exercício dominical." TEPEDINO, Gustavo. Os direitos reais no Novo Código Civil. Seminários EMERJ Debate o Novo Código Civil (2002: Rio de Janeiro). Anais. Revista da EMERJ. Rio de Janeiro, número especial, p. 168-176, jul. 2002 a abr. 2003 , p. 172

so "Salientamos que, até agora, cuidamos dos limites objetivos, isto é, dos estabelecidos pela lei. Ao lado deles, a teoria da relatividade dos direitos insere limites subjetivos, inspirados na idéia de que, no exercício de qualquer direito, e também no do direito de propriedade, deve o respectivo titular ter em vista a razāo de sua instituição, isto é, a razāo pela qual se julgou útil e conveniente, sob o aspecto social, conferir a prerrogativa ao ente privado. Todo direito tem uma função social a desempenhar e deve ser exercido na direção de tal função, vale dizer, funcionalmente. Os desvios, que afastem o exercício do direito da razão determinante de sua instituição, sāo antifuncionais e, portanto, abusivos." BESSONE, Darcy. Direitos reais. São Paulo: Saraiva, 1988. p. 194.

51 "A função social da propriedade (que seria melhor entendida no plural, "função social das propriedades'), realiza-se ou não, mediante atos concretos, de parte de quem efetivamente tem a disponibilidade física dos bens, ou seja, do possuidor." ZAVASCKI, Teori Albino. A tutela da posse na Constituição e no Novo Código Civil. Revista Ibero-Americana de Direito Público, Rio de Janeiro, v. 4, n. 13, p. 243-254, jan./mar. 2004, p. 243. 
funcional do objeto ${ }^{52}$ não é dever exclusivo do senhor da coisa, sendo extensível a todo aquele que a possua, independentemente do título que ostente.

Neste contexto, entendemos que legislador civil de 2002 poderia ter sido mais enfático quando do tratamento da função social da propriedade, assim como o foi em relação à função social do contrato, vinculando-o diretamente, conforme o art. 421 , CC.

De todo modo, a função social da propriedade passa a ser identificada como elemento essencial ao domínio. Neste passo, distingue-se ontologicamente a função social das limitaçōes estabelecidas com base nos direitos de vizinhança - restrições de ordem privada, externas ao direito real - cujo assento legal subsiste desde o Código Civil de 1916.

A identificação da função em seu conteúdo e, por conseqüência, seu fundamento e limitação, é claramente exposta por Perlingieri: ${ }^{53}$

Em um sistema inspirado na solidariedade política, econômica e social e ao pleno desenvolvimento da pessoa (art. 2 Const.) o conteúdo da função social assume um papel de tipo promocional, no sentido de que a disciplina das formas de propriedade e as suas interpretações deveriam ser atuadas para garantir e para promover os valores sobre os quais se funda o ordenamento. E isso não se realiza somente finalizando a disciplina dos limites à função social. Esta deve ser entendida não como uma intervenção "em ódio" à propriedade privada, mas torna-se "a própria razão pela qual o direito de propriedade foi atribuído a um determinado sujeito", um critério de ação para o legislador, e um critério de individuação da normativa a ser aplicada para o intérprete chamado a avaliar as situações conexas à realização de atos e de atividades do titular.

Tende-se, portanto, a não mais se tolerar a propriedade urbana improdutiva, ${ }^{54}$ sendo mitigada da disponibilidade do dono da coisa a perpetuidade de seu direito, justamente por não ser assim considerado. Neste ponto há de prevalecer o dever presente na dominialidade de conceber uma finalidade positiva à área.

Identifica-se, pois, a possibilidade de conflitos entre o direito de propriedade e o dever de observância de sua função social..$^{55}$ Sob a ótica da atual normativa

52 "Função é satisfaçāo de uma necessidade. Toda necessidade pressupōe uma relação entre ela e um bem apto a satisfazê-la (interesse), na esfera jurídica de um sujeito (pertinência)." MORAES. José Diniz de. A função social da propriedade e a Constituição de 1988. São Paulo: Malheiros, 1999, p. 89.

53 PERLINGIERI. Op. cit., p. 226.

${ }_{54}$ "A funçāo social da propriedade pode ser entendida como uma riqueza, da qual o proprietário é possuidor e que se destina à produção de bens, para satisfazer suas necessidades, de sua família, e da comunidade a que pertence." SILVA, Fernanda Duarte Lopes Lucas da. A Lei de Uso, Parcelamento e Ocupação do Solo (LUPOS) do Município de Petrópolis - Lei 5.393/98 - e os princípios constitucionais da função social da propriedade e da proporcionalidade. Revista da Faculdade de Direito da Universidade Católica de Petrópolis. Porto Alegre: Síntese, v. 4, p. 21-50, 2002. p. 33.

55 "A doutrina se tornara de tal modo confusa a respeito do tema que acabara por admitir que a propriedade privada se configura sob dois aspectos: como direito civil e como direito público subjetivo. 
civil, tais confrontos serão dirimidos em favor do promotor dos interesses sociais e econômicos, opção legislativa expressa na regulação das hipóteses de perda e aquisição da propriedade.

No regramento da acessão, por exemplo, o Código Civil de 2002 inovou, como dispōem os arts. 1.253 a 1.259, surgindo algumas exceções ao princípio - outrora absoluto - da superficies solo cedit, absorvendo entendimento já pacificado em sede pretoriana.

A acessão consiste em acréscimo que, embora reconhecível em sua individualidade, não é passível de destacamento sem prejuízo para o todo. Por tal constituição, é considerada um plus à propriedade urbana, integrando sua unidade. É forma de aquisição da propriedade, distinguindo-se do direito de construir que se insere no exercício do direito real, originando uma edificação em terreno próprio. ${ }^{56}$

A normativa civil elegeu como critérios para aquisição da propriedade, em casos em que a acessão e o solo pertençam a pessoas distintas, a boa-fé do agente e a proporção de invasão em terreno alheio, de modo a ser privilegiado, num primeiro momento, o valor econômico da construçāo, muitas vezes bastante superior ao do terreno urbano.

Entretanto, o aspecto econômico, embora primordial, não esgota a matéria. Deve ser coadunado com a boa-fé do construtor, o que viabilizará ou não a reversão da titularidade do solo, fixando-se, em caso de má-fé do invasor, o valor da indenização devida, na forma dos arts. 1.258 e 1.259, CC.

A determinação da aquisição da propriedade urbana daquele que produz, em detrimento do proprietário inerte, demonstra a opção do legislador pela função social quando em conflito com a propriedade, identificando obrigações a serem cumpridas pelo dono do bem, correspondentes aos seus direitos, como bem destacado na doutrina de Teori Albino Zavascki. ${ }^{57}$

Também no que toca à usucapião, a lei civil vigente promoveu mudanças importantes ao fixar uma considerável redução dos prazos para aquisição de propriedade urbana, mediante o exercício da posse vestida de animus domini.

Essa dicotomia fica superada com a concepção de que o princípio da funçāo social da propriedade é um elemento do seu regime jurídico; é um princípio ordenador da propriedade privada; incide no conteúdo do direito de propriedade; impōe-lhe novo conceito." SILVA, José Afonso da. Disciplina jurídico-urbanística da propriedade urbana. Revista de Direito Administrativo, Rio de Janeiro: Renovar, v. 142, p. 1-10, out./dez. 1980. p. 2-3.

56 MEIRELLES, Hely Lopes. Direito de construir. 4. ed. atual. São Paulo: Revista dos Tribunais, 1983, p. 11.

5. “Assim também pode ocorrer, eventualmente, entre direito de propriedade e funçāo social da propriedade. Não obstante sua inegável relaçāo de complementariedade e, quando vistos no plano normativo, da natural aptidāo para sua convivência harmônica, pode ocorrer que, em determinadas situações concretas, não seja possível o pleno atendimento de um deles sem comprometer, ainda que em parte, o outro, ou vice-versa. É o que ocorre, por exemplo, quando, em relação a determinado bem, o detentor da titulação jurídica é omisso no desempenho da funçāo social, a qual, todavia, vem sendo exercida por longo tempo e em sua plenitude por outrem, possuidor não-proprietário." ZAVASCKI. Op. cit., p. 244. 
No entanto, ao estabelecer tal redução, cuidou o legislador de velar pela segurança jurídica, prevendo, nas disposiçōes finais, regra de transiçāo prevista no art. 2.029, CC, evitando qualquer surpresa ao proprietário inerte.

Do mesmo modo, houve a absorção pela lei civil da usucapião especial urbana, com a previsão de prazo qüinqüenal no caso de fixação de moradia em área urbana, transcrevendo a regra do art. 183 da Carta Constitucional.

A hipótese mencionada trata da usucapião pro morare, sendo a função social do bem seu fundamento principiológico ${ }^{58} \mathrm{De}$ fato, o exercício da posse garante ao ocupante a aquisição não apenas do direito real de propriedade, mas do direito à moradia, ${ }^{59}$ consagrado pela Emenda Constitucional 26 como direito social fundamental.

O prestígio ao princípio da funçāo social também é identificado na lei civil por meio da leitura do art. 1.228, $\$ 4^{\circ}$, que traz hipótese de aquisição de domínio pelos possuidores de imóvel reivindicado por seu proprietário.

Também nesta nova modalidade de perda da propriedade a lei regulou a aplicação no direito intertemporal, prevendo norma de transição no art. 2.030, CC, referente ao acréscimo de dois anos ao prazo qüinqüenal estabelecido.

A análise do instituto inovador, já denominado pela doutrina como desapropriação judicial, ${ }^{60}$ vem suscitando várias discussões não só em relação ao seu procedimento, mas também no que toca ao seu assento constitucional. ${ }^{61}$

Os argumentos ventilados acerca da inconstitucionalidade da previsão legal têm por fundamento a separação de Poderes, argüindo-se não competir ao Judiciário a análise da conveniência ou oportunidade de se efetivar uma desapropriaçāo. ${ }^{62}$

Em sentido contrário, há ${ }^{6 s^{63}}$ que aceitam validamente a emanação do ato expropriatório pelo Poder Judiciário, por inexistir regra legal a determinar a exclusividade do Poder Executivo no exercício de tal prerrogativa. Admitem, assim, a aplicação do instrumento, permitindo a análise das circunstâncias do caso concreto na defesa daqueles que tornaram produtivo o solo urbano.

58 GASPARINI, Diógenes. O Estatuto da Cidade. São Paulo: NDJ, 2002. p. 75.

59 ALFONSIN, Betânia de Moraes. Da usucapiāo de imóvel urbano. In: MATTOS, Liana Portilho (Org.). Estatuto da Cidade comentado: lei 10.257, de 10 de julho de 2001. Belo Horizonte: Mandamentos, p. 151-166, 2002.

60 SALLES, José Carlos de Moraes. Usucapião de bens imóveis e móveis. 6. ed. rev. ampl. e atual. de acordo com o Código Civil de 2002. São Paulo: Revista dos Tribunais, 2005. p. 493.

61 Enunciado 82 da Jornada de Direito Civil promovida pelo Conselho da Justiça Federal: "É constitucional a modalidade aquisitiva de propriedade imóvel prevista nos $\$ \$ 4^{\circ}$ e $5^{\circ}$ do art. 1.228 do novo Código Civil."

62 AVELAR, Mateus Rocha. Desapropriação judicial no Novo Código Civil: inconstitucionalidade. Boletim de Direito Administrativo, São Paulo, v. 20, n. 1, p. 46-52, jan./2004, p. 51.

63 MALUF, Carlos Alberto Dabus. Dos direitos reais. In: FIUZA, Ricardo. (Org.). Novo Código Civil comentado. 2. ed. São Paulo: Saraiva, 2004. p. 1132. 
Indicando a existência de mácula constitucional, o professor Caio Mário da Silva Pereira $^{64}$ defende a impossibilidade de a normativa civil inovar, elencando mais uma hipótese de perda da propriedade, direito individual garantido pela Carta Constitucional. Aduz o eminente civilista ser a previsāo ainda mais gravosa por prejudicar o domínio do proprietário em favor não do interesse público, mas de particulares.

Ousamos ${ }^{65}$ discordar de tal posicionamento por entender ser a matéria, forma de aquisição e perda da propriedade, objeto de regulação pela normativa civilista ordinária, não consistindo tema constitucional material a ensejar o vício de nulidade alegado. É dispensável, portanto, assento constitucional, sendo absolutamente admissível a ampliação das hipóteses de perda da propriedade pela lei civil.

No mesmo sentido, parece-nos inadequada a nomeação do instituto como desapropriação, vez existirem no ordenamento outras hipóteses de transferência compulsória de bens, ${ }^{66}$ sem por isso caracterizarem tais institutos como desapropriação.

O texto legal contém diversos conceitos jurídicos indeterminados, tais como "extensa área", "considerável número de pessoas" e "obras e serviços de interesse social e econômico relevante", todos a terem seu conteúdo delineado pelo julgador da causa.

Apesar das críticas quanto à maleabilidade do dispositivo legal, ${ }^{67}$ entendemos adequado o voto de confiança transferido ao Poder Judiciário, por ser o juiz a única autoridade capaz de, no caso concreto, aferir o preenchimento dos requisitos legais e a presença dos valores sociais que se pretende tutelar.

Por outro lado, a diversidade regional do Brasil está a indicar a adoção de conceitos passíveis de adequação ao caso concreto, sob pena de estabelecer normas inexeqüíveis em razão da realidade social vivida.

Neste passo, verificada pelo magistrado a reunião dos preceitos legais no curso de ação reivindicatória, ${ }^{68} \mathrm{o}$ julgador determinará a transferência da propriedade aos possuidores, mediante o pagamento de justa indenização, valendo a sentença judicial como título, na forma do disposto pelo art. $1.228, \$ 5^{2}, \mathrm{CC}$.

A doutrina diverge quanto a quem deva pagar a indenização estabelecida, existindo entendimento de que tal obrigação é do Poder Público. ${ }^{69}$ É já majoritário, no

\footnotetext{
54 PEREIRA, Caio Mário da Silva. Crítica ao anteprojeto de Código Civil. Revista Forense, Rio de Janeiro: Forense, ano 69 , v. 242, fasc. 838,839 e 840 , p. 16-24, abr./jun. 1973, p. 21.

65 No mesmo sentido SALLES. Op. cit., p. 166.

${ }^{66}$ Inserem-se neste rol as hipóteses de alienação judicial de bens, seja em execuçāo singular ou coletiva, de devedor solvente ou não.

67 VENOSA, Sílvio de Salvo. Direito civil: direitos reais. 2. ed. São Paulo: Atlas, 2002. p. 203.

68 Enunciado 83 da Jornada de Direito Civil promovida pelo Conselho da Justiça Federal: "Nas açōes reivindicatórias propostas pelo Poder Público, não são aplicáveis as disposiçōes constantes dos $\$ \mathbb{S}^{\circ} \mathrm{e}$ $5^{\circ}$ do art. 1.228 do novo Código Civil."

69 FACHIN, Luiz Edson. Direito das coisas. Seminários EMERJ Debate o Novo Código Civil (2002: Rio de Janeiro). Anais. Revista da EMERJ. Rio de Janeiro, número especial, p. 140-144, jul. 2002 a abr. 2003, p. 141.
} 
entanto, que tal valor seja custeado pelos possuidores. ${ }^{70}$ Adotamos esta posição, não obstante se reconheça a inviabilidade, muitas das vezes, da transferência do domínio, diante da vinculação da eficácia da sentença a este pagamento.

Impõe-se destacar a residual aplicação que deverá se dar à norma em comento em razāo do advento do Estatuto da Cidade. A Lei 10.257/01 previu, em seu art. 10 , o instituto da usucapião coletiva, forma originária de aquisição da propriedade urbana, cuja estrutura apresenta os mesmos requisitos desta agora chamada desapropriação judicial, com a vantagem de dispensar pagamento de indenização.

Em ambos os institutos de regularização fundiária haverá a dificuldade comum residente na efetivação do registro público imobiliário, vez que mister se fará o adequado parcelamento do solo ou da edificação, tendo a Medida Provisória 2.220 revogado o dispositivo previsto no art. 55 da Lei 10.257/01, que excepcionava tal exigência.

Ressalte-se não se pretender minorar o valor da regra em destaque, reconhecendo-se sua importância na evolução da mens legislatoris, bem como sua relevância prática em áreas rurais não abrangidas pela normativa urbana e em situaçōes nas quais os possuidores sejam titulares de outros direitos reais. O que se visa com a presente análise é tão-somente a sua inserção no ordenamento jurídico posto, de modo a evitar conflitos e antinomias aparentes.

Em outra modalidade de perda da propriedade, confirmando a adoção da função social como diretriz da normativa civil de 2002, o Código Civil remodelou o instituto do abandono.

Não obstante não previna a subutilização do solo urbano, situação somente afetada com os instrumentos urbanísticos a seguir analisados, o art. 1.276 determina um período relativamente curto para caracterizar o abandono de imóvel como causa de extinção da propriedade, revertendo-a em favor do Poder Público Municipal.

Aqueles que alegam a inconstitucionalidade da norma ${ }^{71}$ fazem-no sob o fundamento de não poder a disposição civil inovar em hipótese de expropriação, vez não haver previsão de justa indenização, tampouco de devido processo legal. Aduz-se, ainda, a utilização da mora fiscal como instrumento confiscatório, violador de garantia constitucional individual da propriedade.

Não vislumbramos qualquer vício a macular a norma, porquanto a transferência de propriedade entre particulares é matéria eminentemente civil, a ser tratada e regulada pela normativa infraconstitucional, como já exposto.

\footnotetext{
70 VENOSA. Op. cit., p. 203; ZAVASCKI. Op. cit., p. 247. Neste sentido, Enunciado 84 da Jornada de Direito Civil promovida pelo Conselho da Justiça Federal: “A defesa fundada no direito de aquisição com base no interesse social (art. 1.228, $\$ \$ 4^{\circ}$ e $5^{\circ}$, do novo Código Civil) deve ser argüida pelos réus da açāo reivindicatória, eles próprios responsáveis pelo pagamento da indenização."

7 NISHIYAMA, Adolfo Mamoru. A inconstitucionalidade do artigo 1.276 do novo Código Civil e a garantia do direito de propriedade. Revista dos Juizados Especiais, Sāo Paulo, ano 9, v. 31, p. 23-36, jan./mar. 2004.
} 
Ademais, para a caracterização do abandono hábil a determinar a perda do domínio, nāo bastará a mora fiscal, devendo-se comprovar a ausência da posse sobre o imóvel, na forma do art. $1.276, \$ 2^{\circ}$, CC, não consistindo, assim, em medida de intervenção de natureza confiscatória.

\section{A propriedade urbana regida pela legislação urbanística}

A aglomeração populacional em pequeno espaço de terra e a concentração de variadas demandas sociais impōem ao ordenamento urbanístico a difícil tarefa de coadunar os interesses privados, preservando o atendimento aos interesses primordiais da coletividade, impondo-se aqui a transcrição da lição do Mestre Hely Lopes Meirelles: ${ }^{i 2}$

Para o atingimento desse desiderato, não basta a racionalização do traçado urbano, nem a eficiência dos serviços públicos. Necessário se torna a limitação do uso da propriedade particular, e, notadamente, o condicionamento das construções a índices técnicos e a preceitos urbanísticos de funcionalidade da cidade. E as razões são óbvias: a excessiva concentração populacional, a indiscriminada utilização da área urbana, a localização inadequada das atividades humanas e fatores outros de desajustamento entre a população e o ambiente causam transtornos insuportáveis para a vida urbana, desequilibrando o trinômio: área - população - equipamento.

Célula fundamental no crescimento ordenado das grandes cidades, a propriedade urbana, delineada pela normativa civil-constitucional, sofrerá forte influência do ordenamento urbanístico. ${ }^{73}$

Intrínseco ao Direito Administrativo, o Direito Urbanístico ocupar-se-á da regulação das relaçōes privadas, públicas e coletivas estabelecidas entre os citadinos, no intuito de promover o bem-estar de todos os ocupantes de determinado espaço geográfico.

O panorama aqui traçado é o fundamento basilar da grande incidência de limitações administrativas no solo urbano, fiscalizadas por meio do poder de polícia, institutos já comentados, que virão a condicionar o exercício das liberdades privadas, estabelecendo o traçado e o uso do espaço urbano. ${ }^{74}$

\footnotetext{
72 MEIRELLES. Op. cit., p. 103.

3 "A determinaçāo do direito de propriedade urbana é fruto dos planos urbanísticos (gerais e especiais) e de outros procedimentos e normas legais, que definem a qualificação urbanística para cada parcela de terreno, determinando-se, assim, o objetivo da propriedade." SILVA, José Afonso da. Direito urbanistico... Op. cit., p. 75.

it Diogo de Figueiredo identifica três grandes grupos de problemática urbanística a serem enfrentados: a distribuição do uso do solo urbano, a restrição de seu uso e o condicionamento do uso, indicando para cada grupo instrumentos jurídicos pertinentes. Consulte-se MOREIRA NETO. Op. cit., p. 94-95.
} 
O aproveitamento do solo urbano terá vários de seus aspectos controlados pelo ordenamento urbanístico tais como sua dimensão, localização, edificação, ocupação, afastamento dos terrenos vizinhos e instalação de equipamentos sanitários.

A aplicação de tal controle na realidade concreta será viabilizada pela fixação de parâmetros objetivos, limites técnicos de conteúdo específico, traçados por normas de planejamento urbano. São, portanto, os regramentos de planejamento urbano os instrumentos necessários a concretizar, a individualizar os valores, conceitos e princípios previamente estabelecidos nas normas de Direito Urbanístico. Tal distinção é fundamental para a análise das competências dos Entes Federativos neste campo de atuação, ${ }^{75}$ não sendo este o objeto do presente trabalho, apesar da reconhecida relevância do tema.

Especialmente no que toca à propriedade urbanística, o equilíbrio entre os interesses envolvidos deve ser mais atentamente observado, vez que a valorização do imóvel dar-se-á, na maioria das vezes, em razão da intervenção do setor público.

Isto porque não há, como na propriedade agrícola, participação decisiva do particular. No caso do imóvel urbano, a valorização e a rentabilidade do bem decorrem da ação conjunta dos setores público e privado, de modo a todo o grupo social contribuir para este processo. ${ }^{76} \mathrm{~A}$ propriedade situada em solo urbano é produto cultural, fruto da atividade humana, sujeitando-se a diversas limitações administrativas oriundas do Direito Urbanístico.

No intuito de confirmar a tese aqui exposta, verifica-se que comumente são considerados no cálculo do valor da terra urbana não apenas os direitos já incorporados à propriedade, vez que exercidos pelo particular, mas também as faculdades de ordem pública ainda não inseridas juridicamente no seu patrimônio.

Trata-se de potencialidades gratuitamente conferidas ao particular, por força de ato normativo, não tendo este em nada contribuído para sua configuração. ${ }^{77}$ Observa-se, assim, como a atuação do Poder Público é determinante na fixação da expressão econômica da terra urbana, suscitando sempre interaçōes com a esfera individual patrimonial. Esta atuação é exercida com base na soberania estatal, fundamento maior das diversas limitaçōes administrativas incidentes no solo urbano.

Daí por que, como desenvolvido na doutrina atual, ${ }^{78}$ as limitações urbanísticas distinguem-se ontologicamente da observância da função social da propriedade e das restrições estabelecidas em razão dos direitos de vizinhança.

\footnotetext{
is "A diferenciaçāo feita resulta sobretudo da realidade técnica do próprio urbanismo: os seus aspectos conceituais e a previsão instrumental, que seriam objeto do direito urbanístico, e as regras materialmente operacionais - que determinam e aplicam os conceitos e princípios em determinado local, em um determinado tempo - que denominamos regras de planejamento urbano." Adotamos o conceito doutrinário desenvolvido em RABELLO DE CASTRO. O poder de polícia... Op. cit., p. 143.

i6 GRAU. Aspectos jurídicos... Op. cit., p. 18.

7 RABELLO DE CASTRO. O Estado... Op. cit., p. 140.

-8 Por todos, RABELLO DE CASTRO. O Estado... Op. cit., p. 47.
} 
De fato, as restrições civis, ainda que previstas por normas de ordem pública, são definidas no intuito de preservar os interesses individuais de particulares reciprocamente considerados. Conforme a lição de Hely Lopes Meirelles, são prescritíveis, renunciáveis e transacionáveis.

Já as limitações urbanísticas são determinadas em prol de toda a coletividade, consistindo normas públicas exorbitantes da seara privada, sendo por isto mesmo imprescritíveis, irrenunciáveis e intransacionáveis. ${ }^{79}$

Em razão da pluralidade de interesses envolvidos, a nova configuração da propriedade urbanística pretende evitar a prática de especulação imobiliária, com a retenção de áreas desocupadas, ociosas à espera da estrutura urbana a ser implantada pelo Poder Público, revertendo com exclusividade ao particular lucros oriundos do investimento de dinheiro público, empregado pelo Estado em prol da coletividade.

Importante diploma urbanístico, a Lei 6.766/79 regulamentou o parcelamento para fins urbanos, ${ }^{80}$ estabelecendo responsabilidades para o particular e para a Administração Municipal. Neste sentido, afastou o tratamento civilista adotado pelos diplomas anteriores ${ }^{81}$ enfocando como objetivo primeiro o ordenamento do uso do espaço urbano onde se estabelecia determinado grupo social. ${ }^{82}$

Ocupou a normativa em comento de definir conceitos relevantes como loteamento e desmembramento, ${ }^{83}$ ferramentas necessárias ao combate à clandestinidade da ocupação do solo urbano. Gradualmente, é reconhecida a prevalência do interesse público sobre o privado, fixando proporções entre áreas públicas e privadas, definindo como de domínio público as vias, os edifícios públicos e equipamentos comunitários necessários ao adequado aproveitamento da área, assim previstos no projeto e no memorial descritivo.

Outra importante contribuição da lei federal foi a previsão de áreas non aedificandi, revelando neste particular não apenas um cuidado urbanístico, mas também a preocupação com o meio ambiente natural.

\footnotetext{
79 "Ambas incidem sobre o mesmo objeto - a propriedade privada - mas com finalidades diversas: as restriçōes civis protegem especificamente os vizinhos - uti singuli; as limitaçōes administrativas protegem, genericamente, a coletividade - uti universi." MEIRELLES. Op. cit., p. 69.

${ }^{80}$ 'Observe-se que a Lei 6.766/79 nāo veio regular simplesmente o 'parcelamento do solo urbano', mas sim o 'parcelamento para fins urbanos', o que, evidentemente, abrange especialmente aqueles loteamentos para fins urbanos na zona rural." MUKAI. Op. cit., p. 122.

81 "O DL 271/67, diversamente do DL 58/37, já trazia alguma tutela ao interesse público, ao prever a dominialidade pública das vias e áreas destinadas a equipamentos urbanos, desde o registro do projeto em seu art. 4 e a ausência de indenização de benfeitorias erigidas em loteamentos clandestinos desapropriados, na forma do seu art. $5^{\circ}$." LEAL, Rogério Gesta. Os desafios da administraçāo pública em face do parcelamento do solo urbano: perspectivas jurídicas e políticas. A\&C Revista de Direito Administrativo e Constitucional. Belo Horizonte, ano 5, n. 21, p. 11-32, jul./set. 2005, p. 15.

82 MUKAI, Toshio; ALVES, Alaor Caffe; LOMAR, Paulo José Villela. Loteamentos e desmembramentos urbanos: comentários à Lei 6.766, de 19-12-1979. 2. ed. São Paulo: Saraiva, 1987. p. 2.

83 Tal distinção advém desde o Decreto-lei $271 / 67$ e se fazia necessária, vez que eram inúmeros os loteamentos clandestinos realizados sob o nome de desmembramentos. LEAL. Os desafios ... Op. cit., p. 14.
} 
A norma federal em comento apresenta o loteamento urbano como um processo de urbanizaçāo, abordando seus aspectos administrativos, ecológicos, civis e penais envolvidos na atuação conjunta do particular, da coletividade e do Poder Público.

Algumas décadas depois do advento da Lei $6.766 / 79$, densificando os arts. 182 e 183 da Constituição da República, ingressou no ordenamento jurídico, em 10 de julho de 2002, a Lei 10.257, nomeada Estatuto da Cidade, que, entre outras matérias, trouxe um elenco de instrumentos jurídicos para a implementação da ordenação urbanística e da regularizaçāo fundiária, visando à concretizaçāo da função social da propriedade imobiliária urbana.

A legislação estabelece no art. $1^{\circ}$, parágrafo único, serem as normas ali trazidas de ordem pública, regulando o uso da propriedade urbana, em prol do bem coletivo, ambiental e do bem-estar dos cidadãos. ${ }^{84}$

A ordem urbanística consiste, portanto, num conjunto de imposições vinculantes que condicionam a ação na cidade ${ }^{85}$ Trata-se de normativa cogente, indisponível ao proprietário, que deverá obedecer-lhe, sob pena de nele incidirem os instrumentos previstos na lei.

Neste ponto, importa realçar não serem apenas normas federais - de natureza civil - aptas a modelar o exercício da propriedade urbana. Como instituto multidisciplinar que se apresenta, será o domínio também regulado por normas estaduais e municipais que visem à proteção de interesses públicos e sociais, decorrentes do exercício do poder de polícia de cada ente federativo, observada a repartição de competência constitucional. ${ }^{86}$

A fim de estabelecer a política urbana, a lei federal, pressupondo os deveres estatais de ordenar e controlar o emprego do solo urbano e proteger o patrimônio público, estabelece, em seu art. $2^{\circ}$, diretrizes a serem seguidas pela sociedade e pelo Poder Público, com a utilização de instrumentos tributários, urbanísticos e ambientais e de planejamento.

$\mathrm{O}$ art. $2^{\circ}$, VI, e suas alíneas prevêem a autorização legislativa, ou melhor, a imposição legislativa ao Poder Público local de interferência no conteúdo da propriedade urbana, traçando limites ao seu uso, criando paradigmas ao subuso do bem e vedando seu não-uso.

\footnotetext{
84 "Ainda que as regras urbanísticas possam ser flexíveis, isto é, adaptáveis às circunstâncias que encontram, por serem regras de ordem pública, elas não podem ser dispensadas pela vontade do administrador. Por outro lado, cabe ao cidadāo cumpri-la, já que sāo feitas no interesse geral, e aplicáveis a todos." RABELLO DE CASTRO. Regularizą̧ão fundiária... Op. cit., p. 23.

85 SUNDFELD, Carlos Ari. O Estatuto da cidade e suas diretrizes gerais. In: DALLARI, Adilson de Abreu; FERRAZ, Sérgio (Org.). Estatuto da Cidade: comentários à Lei Federal 10.257/2001. São Paulo: Malheiros, p. 44-60, 2002. p. 54.

86 "A Constituição possibilita a esses entes políticos, dentro do âmbito das matérias de sua competência, estabelecer normas limitadoras do direito de propriedade. Essas limitaçōes encontram, entretanto, os limites não só da própria Constituiçāo, como também das leis federais que dispõem sobre o conteúdo básico do direito da propriedade, isto é, seus elementos formadores." RABELLO DE CASTRO. O Estado... Op. cit., p. 13.
} 
O Estatuto da Cidade, portanto, contribui para a regularização do adequado uso da propriedade urbana; municia o Poder Público local do aparato legislativo necessário à aplicação de sanções urbanísticas nos casos cabíveis, dotando de eficácia social as normas constitucionais anteriormente analisadas.

Outrossim, insta registrar a obrigatoriedade por parte do Ente Municipal de produzir o aparato legislativo necessário para a efetiva aplicação dos instrumentos estabelecidos, porquanto o bem jurídico tutelado, qual seja, a ordem urbana, apresenta-se indisponível ao Administrador Municipal. ${ }^{87}$

Realce-se apenas, no que tange à desapropriação, prevista no art. $182, \$ 4^{\circ}$, III, CRFB, que se imporá para sua efetivação a observância das normas orçamentárias referentes não só à possibilidade de emissão de títulos, como à efetiva aprovação do Senado Federal, como preceitua a Carta Constitucional.

Neste passo, a Lei $10.257 / 01$ regulamentou alguns instrumentos a serem utilizados pelo Poder Público Municipal, com o objetivo de impor ao proprietário a eficácia da função social de seu bem. ${ }^{88}$

Nos arts. $5^{\circ}$ e $6^{\circ}$ da Lei 10.257/01 encontramos a previsão do parcelamento, da edificação ou da utilização compulsórios, exigindo-se para sua aplicação, além da definição da área em plano diretor, a promulgação de lei municipal específica.

$O$ instituto em tela determina a ablação da perpetuidade, ceifando diretamente a senhoria, por impor ao proprietário o uso de seu bem, por meio de parcelamento ou edificação. Igualmente não é tolerado o subuso do imóvel. Consiste num dos mais fortes instrumentos de combate à especulação imobiliária, sendo necessária sua previsão constitucional, diante do forte impacto refletido no conteúdo econômico da propriedade..$^{89}$

Trata-se de uma obrigação de fazer, prestação positiva imposta ao dono do imóvel. A doutrina ${ }^{90}$ indica como espécie de obrigação propter rem, em razão de o vínculo ser estabelecido com base na titularidade de direito real, passando a ocupar o pólo passivo da obrigação. No entanto, tal entendimento permite o abandono da coisa como meio de liberação do antigo proprietário, que não mais poderá ser cobrado pelo cumprimento da obrigação de fazer, frustrando a finalidade da lei.

Por sua vez, é possível também identificar na norma um direito potestativo ${ }^{91}$ público, de modo que o abandono não caracterize a exoneração da obrigação. Nes-

\footnotetext{
8: Há cominação de improbidade administrativa em hipótese de ausência de plano diretor, na forma do art. 52, VII, Lei 10.257/01.

${ }_{88}$ "La función social se traduce en la realización del máximo bienestar colectivo compatible con la situación propietaria." PEREZ-LUN̄O. Op. cit., p. 439.

89. LIRA, Ricardo Pereira. Direito a moradia, cidadania e Estatuto da Cidade. Revista Trimestral de Direito Civil. Rio de Janeiro: Padma, ano 3, v.12, p. 259-291, out./dez. 2002. p. 279.

90 LIRA. Elementos... Op. cit., p. 189.

91 Entendemos por direito potestativo a possibilidade unilateral de o sujeito modificar a situação jurídica de outrem, que se submete aos efeitos desta mudança. Vislumbramos no parcelamento compulsório potestade pública semelhante à identificada na cobrança de imposto real do proprietário e/ou possuidor, situaçāo na qual o abandono não interfere no seguimento da cobrança do tributo.
} 
ta hipótese, permanece o antigo proprietário devedor do implemento da função social do bem, sujeitando-se à sua cobrança, objetivo último da municipalidade $e$ da norma federal..$^{92}$ A questão ainda demanda estudos da doutrina, sendo a definição de sua natureza jurídica dado relevante na aplicação prática do instituto.

Alguns autores, ${ }^{93}$ atentando para a inovação trazida pelo texto legal, que acrescentou o uso, além da edificação e do parcelamento compulsórios, defendem a inconstitucionalidade da norma, por ter extravasado os limites da Carta Constitucional.

Data maxima venia, não coadunamos com tal entendimento porquanto consistirem a edificação e o parcelamento em modalidades do uso, objetivo maior e último do instrumento previsto pela norma constitucional destacada, vez que somente com a adequada destinação do bem haverá cumprimento de sua função social.

Justamente por nos alinharmos a tal corrente, admitimos a compulsoriedade da edificação mesmo em terreno urbano já edificado, porém subaproveitado. $\mathrm{O}$ que se visa, ao fim e ao cabo, é a utilização adequada, não se tolerando a interposição do parcelamento e da edificação como artifícios ao efetivo alcance do objetivo final da norma. ${ }^{94}$

Gize-se, ainda, não ser a alegação de falta de dinheiro do proprietário escusa justificável ao descumprimento do instrumento legal. Nesta hipótese deverá o particular promover a alienação do seu bem, dando fim a uma situação prejudicial à coletividade.

Insta destacar a existência de veto presidencial em inciso do dispositivo legal ora em comento. Fundou-se o referido veto na impossibilidade de vincular subutilizaçāo do imóvel ao seu uso ilegal. Esclarecem as razōes serem conceitos diversos, havendo muitos casos em que o imóvel urbano tem destinação social, embora subsista alguma falha legal, como, por exemplo, de construção.

Entendemos ter agido bem o chefe do Poder Executivo quanto a este dispositivo, por destacar a distinçāo entre legalidade e aproveitamento adequado. Tratase de conceitos de aplicaçôes diversas, a serem utilizados em momentos próprios pelo operador do Direito. ${ }^{95}$

\footnotetext{
92 Tal raciocínio foi desenvolvido nas aulas da matéria Propriedade Urbana, ministradas pelo professor Ricardo Lira, no curso de mestrado em Direito da Cidade.

93 CARVALHO FILHO. Op. cit., p. 74.

94 “Não é qualquer edificação que atenderá à imposição urbanística, pois seria fácil imaginar a burla do dispositivo, construindo um cômodo ou, como forma de represália, um cortiço. Deverá o proprietário atender ao que foi estabelecido pela referida lei ou pelo plano urbanístico, para o local previsto, visando não destoar dos demais padrões existentes." TORRES, Marcos Alcino de. Instrumentos urbanísticos e a propriedade urbana imóvel (implicações e confronto por conta da função social da cidade e da propriedade urbana). In: TEPEDINO, Gustavo. Problemas de direito civil-constitucional. Rio de Janeiro: Renovar, p. 467-513, 2000. p. 485.

95 "O uso ilegal de imóveis urbanos autoriza outras atitudes da Municipalidade, que pode fazer uso de seu poder de autoridade e determinar a lacração, o fechamento, a proibição de entrada nesses imóveis ou, até mesmo, a imposição de multa ao proprietário pelo descumprimento de um dever legal."
} 
Quanto ao seu procedimento, a lei prevê a averbação no registro público da notificação quanto à exigência municipal, nos termos do estabelecido no art. $5^{\circ}, \mathbb{S}$ $2^{\circ}$. Evidente que o interesse maior na observância do requisito registral é do Ente Municipal, que dotará a obrigação urbanística de eficácia erga omnes.

Ainda sobre este aspecto, a doutrina ${ }^{96}$ critica a previsão legal de prazos longos, sucessivos, concedidos ao particular para efetivo implemento de sua prestação, estando neste ínterim prejudicada toda a coletividade.

O IPTU progressivo é previsto no art. $7^{\circ}$ da Lei $10.257 / 01$, sendo expressa a possibilidade de sua aplicação somente após o exaurimento do procedimento determinado para a edificação compulsória, sucessão que em muito dificulta a eficácia destes instrumentos.

Não obstante sua finalidade urbanística, consiste o IPTU progressivo em espécie de tributo, estando subordinado ao princípio da anterioridade da lei fiscal, prevista no art. 150, III, $b$, CRFB.

Destaque-se que a finalidade do imposto progressivo não é tão-somente majorar sua alíquota. O objetivo precípuo é extrafiscal, ${ }^{97}$ consistente na imposição do particular em dar destinação adequada ao seu bem, em prol da cidade onde vive. Difere, portanto, da modalidade tributária prevista no art. $156, \$ 1^{\circ}$, CRFB, que admite a progressividade para fins fiscais.

Em razão da utilização extrafiscal do tributo, o princípio da capacidade contributiva, fundamento basilar do Direito Tributário, cederá ao interesse social tutelado por meio da cominação do imposto. ${ }^{98} \mathrm{O}$ objetivo da norma, repise-se mais uma vez, não é arrecadar aos cofres públicos, mas estimular determinado comportamento visando à concretização da ordenação urbanística.

A extrafiscalidade também é apresentada por parte da doutrina ${ }^{99}$ como fundamento a afastar a alegada existência de confisco, na hipótese de incidência da alíquota em seu grau máximo previsto em lei. Neste caso, a tributação não se

BUENO, Vera Scarpinella. Parcelamento, edificação ou utilização compulsórios da propriedade urbana. In: DALLARI, Adilson de Abreu; FERRAZ, Sérgio (Org.). Estatuto da Cidade: comentários à Lei Federal 10.257/2001. Sāo Paulo: Malheiros, p. 87-100, 2002. p. 100.

96 'Assim, enquanto o 'devido processo legal' de intervenção do Poder Público sobre o imóvel vai-se processando, o indevido processo social sob o qual o referido bem está sendo usado por um em prejuizo de todos, vai cumprindo o seu sinistro papel no fim do qual ainda será indenizado." ALFONSIN, Jacques Távora. Breve apontamento sobre a função social da propriedade e da posse urbanas à luz do novo Estatuto da Cidade. In: OSORIO, Letícia Marques (Org.). Estatuto da Cidade e reforma urbana: novas perspectivas para as cidades brasileiras. Porto Alegre: Fabris, p. 61-76, 2002. p. 71.

97 "A extrafiscalidade consiste na utilização do tributo para obter certos efeitos na área econômica e social, que transcendem a mera finalidade de fornecer recursos para atender às necessidades do Tesouro. TORRES, Ricardo Lobo. Os direitos humanos e a tributaçāo: imunidades e isonomia. Rio de Janeiro: Renovar, 1995. p. 119.

98 COSTA, Regina Helena. Instrumentos tributários para a implementaçāo da política urbana. In: DALLARI, Adilson de Abreu; FERRAZ, Sérgio (Org.). Estatuto da Cidade: comentários à Lei Federal 10.257/2001. São Paulo: Malheiros, p. 101-116, 2002. p. 104.

99 CARVALHO FILHO. Op. cit., p. 89. 
pauta na capacidade econômica do contribuinte, mas no estímulo ao adequado aproveitamento de seu imóvel urbano.

Por outro lado, leciona-nos Ricardo Lobo Torres ${ }^{100}$ não ser a extrafiscalidade por si só suficiente a afastar a ocorrência do confisco. Também em casos de incidência tributária extrafiscal será possivel verificar o efeito confiscatório, devendose preservar o fundamento maior de sua vedação, qual seja, a liberdade, impedindo-se assim o total esvaziamento da riqueza tributada.

O insucesso da incidência do imposto real progressivo determinará a promoção pelo Ente Público Municipal da desapropriação, com pagamento em títulos e não em dinheiro, como na hipótese prevista pelo art. 5ํ, XXIV, da Carta Maior.

Tal modalidade de desapropriação é denominada pela doutrina "desapropriação-sanção", por consistir em uma privação forçada da propriedade urbana, em razão do descumprimento de obrigações e ônus urbanísticos impostos ao proprietário, não sendo o domínio plenamente tutelado pelo ordenamento constitucional. Trata-se, portanto, de uma sanção, por força de seus fundamentos, gerando uma garantia mais branda daquela prevista ordinariamente para os demais casos de desapropriação.

A previsão legal do instituto em análise encontra-se no art. $8^{\circ}$ do Estatuto da Cidade. $O$ dono do bem é indenizado pelo valor real do imóvel, tendo por base aquele considerado para fins de lançamento de IPTU, não se computando lucros cessantes, juros compensatórios, ${ }^{101}$ nem valorizaçōes decorrentes da realização de obras públicas no local.

O art. 182, $\$ 4^{\circ}$, III, Carta Maior é claro ao prever não a justa indenização, como disposto no art. $5^{\circ}$, mas o pagamento do valor real acrescido de juros legais. A lei federal conceitua o valor real expondo ser este, na prática, o valor venal, assim considerado para fins de IPTU, e em regra inferior ao valor de mercado do imóvel, não se computando juros ou lucros cessantes.

Confirmando sua finalidade de estancar a especulação imobiliária, a norma legal estabelece inclusive a dedução, do valor a ser pago, de eventual valorização do terreno em razão da realização de obras públicas.

A definição legal do an debeatur a ser indenizado nesta modalidade de desapropriação pretende, assim, afastar a aplicação dos princípios e normas regentes da desapropriação por utilidade pública ou interesse social, quando o imóvel cumpre sua função social, não merecendo o particular qualquer espécie de diminuição patrimonial, devendo ter seus direitos preservados pela Administração Pública, ao intervir em seu domínio.

\footnotetext{
100 TORRES. Op. cit., p. 113-114.

101 "Na desapropriação em foco, nada há a compensar, visto que o proprietário já há muito vem abusando do direito de propriedade. Compensaçāo por compensaçāo, deveria esta caber ao proprietário em favor da coletividade prejudicada por sua oposiçāo à ordem urbanística." CARVALHO FILHO. Op. cit., p. 107-108.
} 
Neste sentido, é justificável a exclusão dos juros compensatórios e de lucros cessantes, já que inexistentes. Quem não explora seu terreno, não lhe dando uso devido, não tem o que compensar, nem o que lucrar. Qualquer extra auferido será com base no investimento público realizado no local, não devendo o mesmo ser reconhecido ao particular, que em nada contribui para o incremento do bem.

O benefício extraido do não-uso ou do subuso do solo urbano só poderá advir da especulação imobiliária, dos investimentos públicos na urbanização do espaço, sendo tal prática merecedora de sanção e não de restauração.

Os instrumentos jurídicos previstos no art. $182, \$ 4^{\circ}$ traduzem mecanismos eficazes quanto à imposição ao particular do adequado uso do bem. No entanto, a exigência de previsão em plano diretor e em lei específica, bem como a inafastável sucessão das imposições legais, dificulta a implementação fática da normativa, não se coibindo efetivamente a especulação imobiliária tão maléfica ao bom funcionamento dos grandes centros urbanos.

\section{Conclusão}

O presente trabalho abordou a propriedade privada urbana sob diversos prismas jurídicos. Discorreu sobre as normativas reguladoras da senhoria, buscando a uniformização dos conceitos, para um maior aproveitamento de seus efeitos, alcançando as seguintes conclusōes.

A estrutura do conteúdo jurídico dominial reflete as influências políticas e sociais vigentes no Brasil, sendo a propriedade elemento revelador do sistema econômico adotado por determinado grupo social. A análise histórica empreendida demonstrou que o caráter social do domínio não importa inovação, tendo sido uma constante preocupação das sociedades, tema de há muito abordado pelo meio acadêmico.

Verifica-se que a Carta Constitucional de 1988 avançou ao inserir, dentre o rol dos direitos fundamentais, o direito de propriedade e sua observância pela função social. Embora não tenha expressamente reconhecido a vinculação entre ambos para a plena garantia dominial, identifica-se hoje o domínio como instituto provedor também do interesse coletivo, por meio da adequada destinação do bem.

Sob a perspectiva constitucional do instituto, identificamos a propriedade urbana como direito fundamental, já sendo também trabalhado, em sede doutrinária, seu correspondente dever fundamental, sem o qual não é dotada a normativa constitucional de qualquer eficácia.

Expressamente prevista na Carta Maior, a função social é apresentada como princípio constitucional, garantia fundamental e diretriz da ordem econômica, removendo definitivamente a matéria do exclusivo tratamento civil. 
Por todas as vertentes exploradas, conclui-se ser mais recorrente situar a função social como elemento ínsito ao conteúdo da propriedade urbana, integrando sua estrutura. Não é mais considerada limite externo ao exercício do domínio, como verificado nos direitos de vizinhança. A função social passa a ser um critério de graduação da tutela dispensada pelo ordenamento jurídico à dominialidade.

Diante de tal configuração, não mais se confunde a função social com limitações administrativas e com o exercício do poder de polícia, elementos externos, decorrentes da atuação do Ente Público na tutela da necessária ordenação do espaço urbano.

Nesta trilha, constata-se ter o Código Civil de 2002 absorvido os valores constitucionais, revelando-os no regramento das relaçōes privadas. Entre eles, sem dúvida, encontramos a função social da posse e da propriedade urbana realçando o aspecto econômico do bem, delineando e determinando seu uso em atenção aos interesses proprietários e não-proprietários, conforme os valores coletivos vigentes.

Fundamental à exteriorização de tal conteúdo, a posse cada vez mais se apresenta como o principal instrumento na exploração do patrimônio, dando-lhe adequada destinação econômica, atendendo às necessidades individuais e da coletividade. Consiste no fiel da balança em eventual conflito entre o direito real matriz e sua funcionalidade.

O estudo doutrinário da propriedade urbana revela sua metamorfose qualitativa, agregando demandas individuais e coletivas. Hoje, o domínio deve, observando as potencialidades do bem, promover os valores impostos pela realidade social.

A ablação da perpetuidade e a adequação do caráter absoluto do instituto apenas refletem um sentimento social. De fato, as sociedades atuais, hospedeiras de intensa desigualdade social, não mais suportam o desperdício, qualquer que seja ele. Quanto a tal postura não há liberdade, nem discricionariedade. E em se tratando de bem de produção, como é o solo urbano, a situação se agrava, sendo imperiosa a produção de riquezas, determinando a circulação de bens.

O arcabouço urbanístico vem sendo desenvolvido justamente para instigar o proprietário a dotar seu bem de adequada produção, sendo inovador o assento constitucional da política urbana, com a previsão dos instrumentos urbanísticos, mais bem detalhados pela Lei 10.257/01.

Neste ponto, destaque-se a previsão do instrumento do parcelamento, da edificação e do uso compulsórios, a partir do qual não mais se admite o não-uso do imóvel, atingindo-se nuclearmente o atributo da perpetuidade dominial.

A propriedade exercida nas grandes cidades, em razão de seu suporte físico e da intensa concentração de serviços e pessoas, submete-se a um regime específico no qual se potencializam características inerentes à senhoria. Por este motivo, justifica-se uma maior intervenção do Estado na regulação do solo urbano, advindo daí a importância e a atualidade do tema proposto. 